\title{
PREPARATION, IDENTIFICATION AND BIOLOGICAL PROPERTIES OF NEW FLUORIDE NANOCOMPOUNDS
}

\author{
AMIR LASHGARI', SHAHRIAR GHAMAMI', MOJDEH GOLZANI', GUILLERMO SALGADO-MORÁN², \\ DANIEL GLOSSMAN-MITNIK ${ }^{3}$, LORENA GERLI - CANDIA ${ }^{4 *},{ }^{5} B E H N A Z$ ABDOLMALEKI
}

\author{
${ }^{I}$ Department of Chemistry, Faculty of Science, Imam Khomeini International University, Qazvin 34148-96818, Iran. \\ ${ }^{2}$ Departamento de Ciencias Químicas, Facultad de Ciencias Exactas, Universidad Andrés Bello, Sede Concepción, Concepción, Chile. \\ ${ }^{3}$ Laboratorio Virtual NANOCOSMOS, Departamento de Medio Ambiente y Energía, Centro de Investigación en Materiales Avanzados, \\ Chihuahua, Chih 31136, México. \\ 4*Universidad Católica de la Santísima Concepción, Facultad de Ciencias, Departamento de Química Ambiental, Concepción, Chile. \\ ${ }^{5}$ Department of Chemistry, Faculty of Science, Khaje Nasir Toosi University of Technology, Tehran, Iran
}

\begin{abstract}
Nanoparticles (NPs) of new fluoride $\left(\mathrm{SrF}_{2}\right.$ and $\left.\mathrm{MgF}_{2}\right)$ nanocompounds were synthesized by the simple chemical method of precipitation in ethanol. Synthesis of the strontium fluoride $\left(\mathrm{SrF}_{2}\right)$-magnesium oxide $(\mathrm{MgO})$ nanocomposite was achieved through the ultrasonic method. These prepared nanopowders were characterized through Fourier transform infrared (FT-IR) spectroscopy, ultraviolet-visible (UV-Vis) spectroscopy, Powder X-ray Diffraction (PXRD) and Scanning Electron Microscopy (SEM). FT-IR confirmed the purity of the synthesized fluoride NPs by evaluation of the vibrations, and UV-Visible showed the intense absorption peaks of NPs. PXRD analysis indicated the average of particle size, and SEM demonstrated a nearly spherical morphology of the NPs. The antibacterical properties of the nanopowders on Staphylococcus Aureus, Bacillus Subtilis and E. Aklay bacteria were studied, with the strongest effect by the magnesium fluoride $\left(\mathrm{MgF}_{2}\right) \mathrm{NPs}$ and the $\mathrm{SrF}_{2}-\mathrm{MgO}$ nanocomposite.
\end{abstract}

Keywords: Nanoparticle; Nanofluoride; Nanocomposite; Antibacterial activity.

\section{INTRODUCTION}

Nanoparticles (NPs) are defined as particles less than $100 \mathrm{~nm}$ in diameter $[1,2]$. They exist widely in the natural world. For example, preparation of NPs in nature can be caused by photochemical process, volcanic activity or created by plants and etc. Currently, the level of nanomaterials is highly advanced, both in terms of scientific knowledge and in commercial applications. A decade ago, NPs were studied widely because of their size-dependent physical and chemical properties [3] and have now entered a commercial exploration period [4-7].

In order to produce a small particle size, high-speed homogenization or ultrasonication is often employed [8]. Changes in the physical and chemical properties of the materials at the nanoscale have resulted in important applications and received considerable attention in various fields $[9,10]$. In recent years, increasing attention has been paid to the synthesis and characterization of nanomaterials because of their novel chemical and physical properties arising from the large surface to volume ratios and the quantum size effect, compared with those of bulk counterparts [11-15]. They exhibit novel electronic, magnetic, optical, chemical and mechanical properties that cannot be obtained in their bulk counterparts [16-21].

The alkali (IA) metals show a closer relationship in their properties than any other family of elements. They are extremely chemically reactive and never naturally found in the element form. All of these metals react spontaneously with gases in the air and thus, must be stored immersed in oil. The chemical reactivity of the alkali metals increases as the atomic number increases [22]. Almost, most of the compounds of the alkali metals are soluble in water and widely distributed. Alkaline earth halides are also soluble in water [23-26].

In this study, we synthesized nano-sized $\mathrm{SrF}_{2}, \mathrm{MgF}_{2}$ and $\mathrm{SrF}_{2}-\mathrm{MgO}$ that might be used as an agent for dental applications and antibacterial activities. These products were characterized by FT-IR, UV-Visible, PXRD and SEM to understand the influence of the orientation and shape of the resulting nanostructures on bacterial growth parameters.

\section{EXPERIMENTAL}

\subsection{Materials and Instruments}

Strontium chloride $\left(\mathrm{SrCl}_{2}\right.$, magnesium chloride $\left(\mathrm{MgCl}_{2}\right)$, ammonium fluoride $\left(\mathrm{NH}_{4} \mathrm{~F}\right)$, ethanol and ether were acquired from Merck company. Solvents used in reactions were purified and dried by standard procedures. $\mathrm{MgO}$ NPs and Neutrino were purchased from Merck company. Infrared spectra were recorded on potassium bromide $(\mathrm{KBr})$ disks using the Bruker Tensor model 420 spectrophotometer. The UV-Vis spectra were recorded on the Agilent 8453 UV-Vis spectrophotometer. The PXRD measurements of synthesized samples were carried out using the MPD3000 Powder Diffractometer. The surface morphology of the products was characterized with a scanning tunneling microscope (NAMA-STM Model SS2, NATSYCO, Iran). A multiwave ultrasonic generator (Sonicator-3000; Misonix, Inc., Farmingdale, NY, USA), equipped with a converter/transducer and titanium oscillator (horn), $12.5 \mathrm{~mm}$ in diameter, operating at $20 \mathrm{kHz}$ with a maximum power output of $600 \mathrm{~W}$ was used.

\subsection{Synthesis of $\mathrm{SrF}_{2} \mathrm{NPs}$}

$\mathrm{SrCl}_{2}$ was dissolved in anhydrous ethanol and stirred for $1 \mathrm{~h}$ at room temperature to prepare the white solution. $\mathrm{NH}_{4} \mathrm{~F}$ was similarly prepared to generate the colorless solution. Both solutions were mixed together and stirred for $3 \mathrm{~h}$, generating a white precipitate (equation 1).

$\mathrm{SrCl}_{2}+2 \mathrm{NH}_{4} \mathrm{~F} \rightarrow \mathrm{SrF}_{2}+2 \mathrm{NH}_{4} \mathrm{Cl}$

2.3. Synthesis of $\mathrm{MgF}_{2} \mathrm{NPS}$

For preparation of the $\mathrm{MgF}_{2} \mathrm{NPs}, 0.95 \mathrm{~g}$ of $\mathrm{MgCl}_{2}$ was dissolved in distilled water. Then, $0.74 \mathrm{~g}$ of $\mathrm{NH}_{4} \mathrm{~F}$ was added to the $\mathrm{MgCl}_{2}$ solution and stirred for 2 $\mathrm{h}$ (equation 2). The precipitate was washed with ethanol and extracted onto a ceramic dish to dry on a sand bath.

$\mathrm{MgCl}_{2}+2 \mathrm{NH}_{4} \mathrm{~F} \rightarrow \mathrm{MgF}_{2}+2 \mathrm{NH}_{4} \mathrm{Cl}$

2.4. Synthesis of $\mathrm{SrF}_{2}-\mathrm{MgO}$ Nanocomposite

In order to the synthesis of the nanocomposite, $0.75 \mathrm{~g}$ of synthesized $\mathrm{SrF}_{2}$ and $0.25 \mathrm{~g}$ of $\mathrm{MgO}$ were dissolved in $100 \mathrm{~mL}$ of ethanol. The opalescent suspension was collected and sonicated at a frequency of $(>20 \mathrm{kHz})$ for 15 min 70 times. The suspension was then centrifuged for $5 \mathrm{~min}$ at $6000 \mathrm{rpm}$ and the white precipitate was washed twice with ethanol. The precipitate was then extracted onto a ceramic dish and dried on a sand bath, and the resulting powder was cooked in an oven at $300^{\circ} \mathrm{C}$ for $15 \mathrm{~min}$.

\subsection{Bacterial Cell culture}

S. aureus, B. subtilis and E. Aklay were prepared in plates at the Pasteur Institute of Iran. Vials of lyophilized bacteria were opened under aseptic conditions, resuspended in BHI (Brain Heart Infusion) media and incubated for $24 \mathrm{~h}$ at $37^{\circ} \mathrm{C}$. In order to ensure the purity of the bacterial broth, bacteria was cultivated on Macconkey agar plates for $24 \mathrm{~h}$ at $37^{\circ} \mathrm{C}$. Colonies were picked and added to BHI media. The microbial suspension was prepared using a solution of $(0.5 \mu \mathrm{g} / \mathrm{ml})$ that is equivalent to the McFarland standard of $1.5 \times$ $10^{8}$ colony forming units $(\mathrm{CFU}) / \mathrm{ml}$.

To assess the antibacterial properties of the NPs, discs were prepared containing $0.01 \%$ of NPs in the appropriate solvent. The discs were heated for $20 \mathrm{~min}$ at $37^{\circ} \mathrm{C}$. The discs were placed on the bottom of petri dishes and 
Mueller Hinton agar was poured over the discs. After the agar solidified, $S$ aureus, B. subtilis and E. Aklay were plated and incubated for $24 \mathrm{~h}$ in a $37^{\circ} \mathrm{C}$ incubator.

\section{RESULTS AND DISCUSSION}

\subsection{Vibrational spectra}

The vibrational spectra of the synthesized $\mathrm{MgF}_{2}$ NPs shown in the Fig. 1. Several studies have reported a wider absorbance at $435 \mathrm{~cm}^{-1}$ relating to the composition of the Mg-F stretching vibration [28, 29]. FT-IR of reference inorganic compounds indicate that a peak at $477 \mathrm{~cm}^{-1}$ is related to the $\mathrm{Mg}-\mathrm{F}$ stretching vibration [30]. So, a strong absorption peak in the FT-IR spectrum of synthesized $\mathrm{MgF}_{2}$ at $452.99 \mathrm{~cm}^{-1}$ was observed, which is corresponded to the $\mathrm{Mg}-\mathrm{F}$ stretching vibration. The strong peak absorption, in the areas around $3448.22 \mathrm{~cm}^{-1}$ and $1661.58 \mathrm{~cm}^{-1}$, are characteristic of $\mathrm{H}-\mathrm{O}-\mathrm{H}$ bending (of $\mathrm{H}_{2} \mathrm{O}$ molecules) and is indicative of the presence of hydroxyl groups in the sample preparation $[31,32]$.

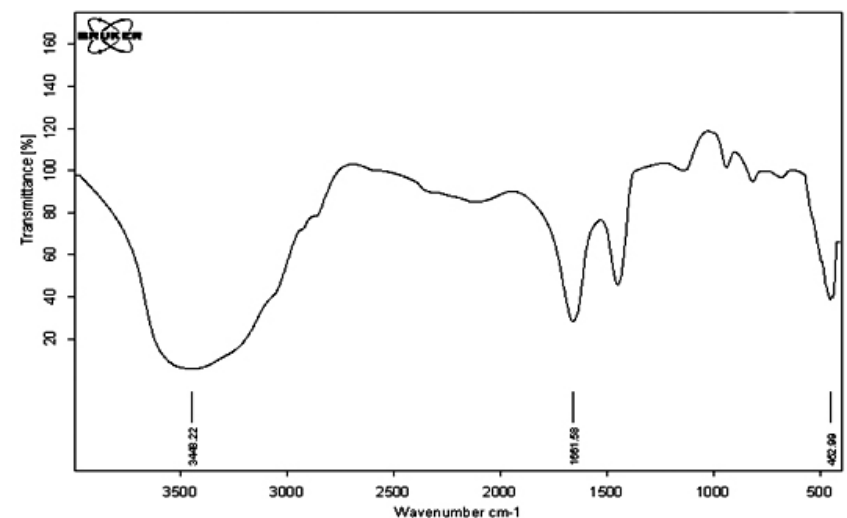

Fig. 1. FT-IR spectra of $\mathrm{MgF}_{2} \mathrm{NPs}$.

Also, the vibrational spectra of the synthesized $\mathrm{SrF}_{2} \mathrm{NPs}$ revealed in the Fig. 2. In this figure, the absorption peak at $441.5 \mathrm{~cm}^{-1}$ is considered to be specifically relevant to $\mathrm{SrF}_{2}[30]$, which is corresponded to the $\mathrm{Sr}-\mathrm{F}$ vibrations. A strong absorption peaks are also visible at 3412.51 and $1648.48 \mathrm{~cm}^{-1}$ which is related to stretching vibration of hydroxyl group $(\mathrm{OH})$ of the absorbed water molecules [31-33].

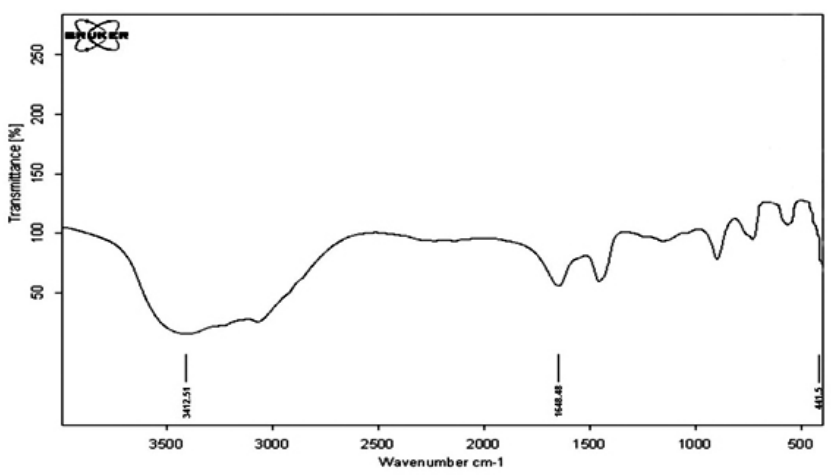

Fig. 2. FT-IR spectra of $\mathrm{SrF}_{2}$ NPs.

The FT-IR spectra of $\mathrm{SrF}_{2}-\mathrm{MgO}$ nanocomposite displayed in Fig. 3. The peaks related to the $\mathrm{Mg}-\mathrm{O}$ and $\mathrm{Sr}-\mathrm{F}$ bonds were observed with a medium intensity at $482.16 \mathrm{~cm}^{-1}$ and $449.56 \mathrm{~cm}^{-1}$ respectively. Again, the peaks at $1063.88,1507.64,2371.48$ and $3470.47 \mathrm{~cm}^{-1}$ belong to stretching and bending vibrations of the hydroxyl group and is due to the absorption of water molecules.

\section{2. $\quad U V-V i s i b l e ~ s p e c t r u m$}

The NPs have characteristic strong absorption peaks at 300 and $310 \mathrm{~nm}$ for $\mathrm{MgF}_{2}$ (Fig. 4) and $\mathrm{SrF}_{2}$ (Fig. 5) respectively. Nano-scale materials have a greater surface to volume ratio, leading to the formation of pores on the surface and inside of dense NPs. The pores are responsible for the main UV absorption
[34]. The greater surface to volume ratio of smaller NPs $(\sim 10-20 \mathrm{~nm})$ also results in the increased distribution of surface defects of nanomaterials, thus, nanomaterials with smaller particle sizes have wide and strong absorption peaks [35] These results are consistent with previous reports [36].

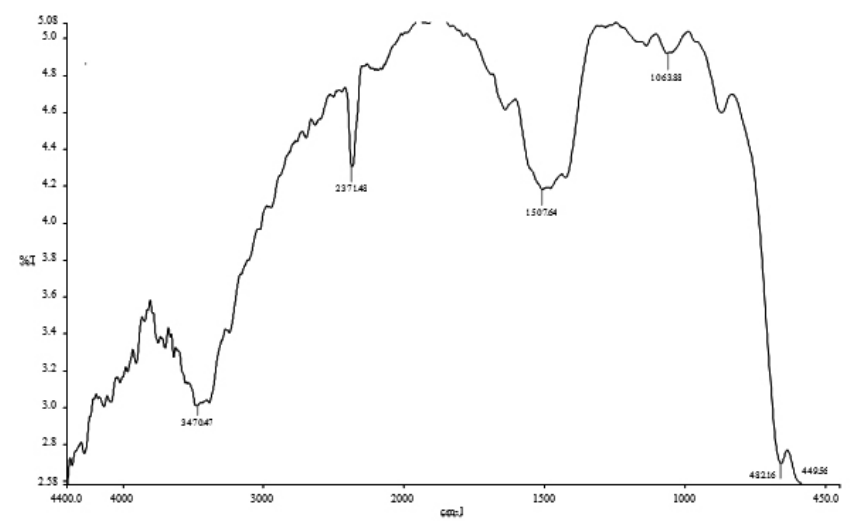

Fig. 3. FT-IR spectra of $\mathrm{SrF}_{2}-\mathrm{MgO}$ nanocomposite.

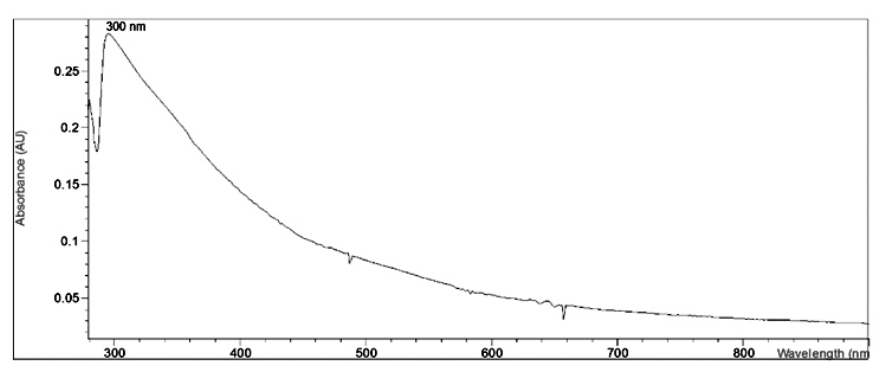

Fig. 4. UV-Vis spectra of $\mathrm{MgF}_{2} \mathrm{NPs}$ in (THF) solvent.

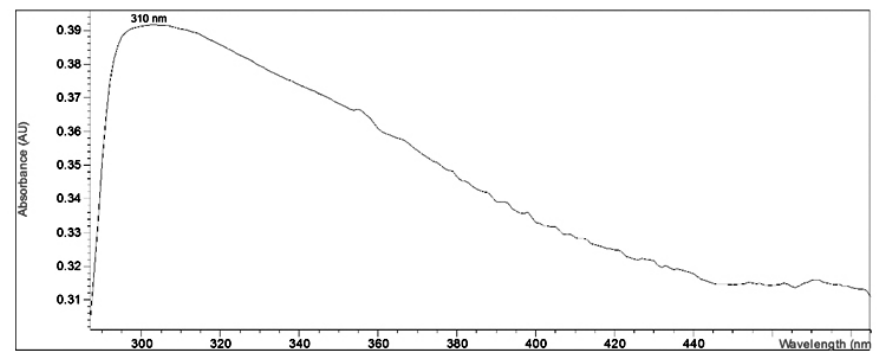

Fig. 5. UV-Vis spectra of $\mathrm{SrF}_{2} \mathrm{NPs}$ in (THF) solvent.

\subsection{PXRD pattern of the synthesized NPs}

The PXRD analysis was performed at a voltage of $40 \mathrm{kV}$ and $\mathrm{K} \alpha$ of copper with the wave length of 1.54 , and calculated using the Debye-Scherrer (equation 3):

$$
\mathrm{D}(\mathrm{nm})=\mathrm{K} \lambda / \beta \cos \theta
$$

In this equation: $\mathrm{D}$ is the size $(\mathrm{nm})$ of the particles; $\mathrm{K}$ is a constant $(0.99) ; \lambda$ is the X-ray $(\mathrm{Cu} \mathrm{K} \alpha)$ wavelength $(0.154 \mathrm{~nm}) ; \beta$ is the width of the peak at half the height; $\theta$ is the diffraction angle in degrees.

\subsection{1. $\mathrm{MgF}_{2} \mathrm{NPS}$}

The PXRD pattern for $\mathrm{MgF}_{2}$ is shown in Fig. 6. The standard card number 00-006-0290 was used as a reference to identify $\mathrm{MgF}_{2}$. The synthesized $\mathrm{MgF}_{2}$ NPs have a tetragonal structure and the space group P42/mnm (136). The observed peaks coincide with the following hkl values: (110), (101), (111), (210), (211), (220), (002), (310), (301), (311), (212), (400) and (222) [27]. Furthermore, the PXRD pattern confirms the formation of the $\mathrm{MgF}_{2} \mathrm{NPs}$. The synthesized powder is crystalline and the width of peaks is consistent with the small particle size. 
The Debye-Scherrer equation and FWHM have been used to calculate particle sizes.

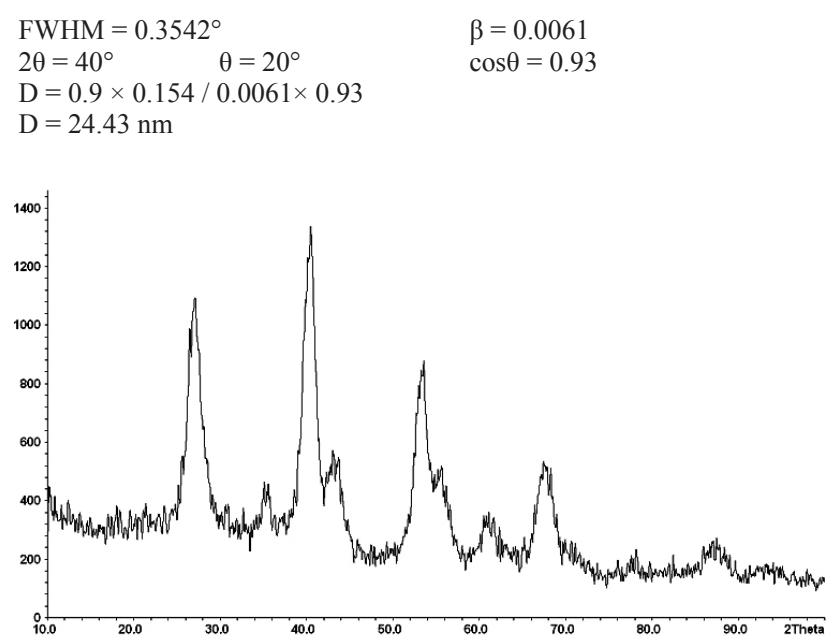

Fig. 6. PXRD pattern of $\mathrm{MgF}_{2} \mathrm{NPs}$.

\subsection{2. $\mathrm{SrF}_{2} \mathrm{NPS}$}

The powder PXRD pattern (Fig. 7) confirm that the preparation was $\mathrm{SrF}_{2}$, supporting the feasibility of preparing NPs of highly insoluble compounds. One of the most important characteristic of strontium phosphate/strontium fluoride materials is their solubility properties because most reactions of these compounds in an aqueous environment are driven by relative solubility/ reactivity of the reactant and product. Although the $\mathrm{SrF}_{2} \mathrm{NP}$ was expected to be more soluble than crystalline $\mathrm{SrF}_{2}$, the solution could precipitate to form crystalline $\mathrm{SrF}_{2}$ during the dissolution process of the $\mathrm{SrF}_{2}$ NPs [37]. The observed peaks coincide with the following hkl values: (111), (200), (220), (311), (222), (400), (331), (420), (422) and (511). The SrF 2 PXRD pattern was also compared with the standard card number 00-006-0262. SrF NPs have a standard cubic structure and the space group $\mathrm{Fm} 3 \mathrm{~m}$ (225), and the status and placement of index peaks are in agreement with references.

$$
\begin{aligned}
& \text { FWHM }=0.1919 \quad \theta=13 \quad \beta=0.0033 \\
& 2 \theta=26 \quad \cos \theta=0.97 \\
& D=0.9 \times 0.154 / 0.0033 \times 0.97 \\
& D=43.29 \mathrm{~nm}
\end{aligned}
$$

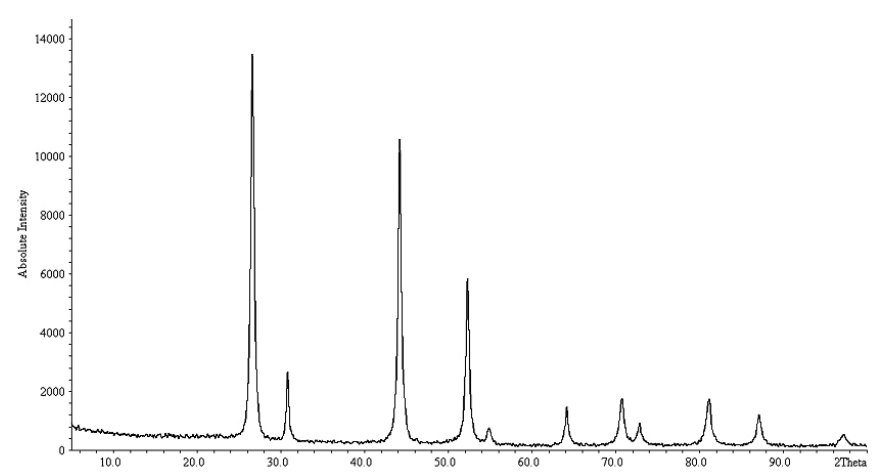

Fig. 7. PXRD pattern of $\mathrm{SrF}_{2} \mathrm{NPs}$.

\subsection{3. $\mathrm{SrF}_{2}-\mathrm{MgO}$ nanocomposite}

The PXRD pattern of the synthesized $\mathrm{SrF}_{2}-\mathrm{MgO}$ nanocomposite is shown in Fig. 8 and was compared with the standard cards numbers 01-075-0447 and 00-006-0262, for $\mathrm{MgO}$ and $\mathrm{SrF}_{2}$, respectively. According to PXRD pattern, the $\mathrm{SrF}_{2}-\mathrm{MgO}$ nanocomposite have the standard cubic structure and the space group Fm3m (225). The status and placement of the index peaks are in agreement with the references, and the observed peaks are completely in coincidence with reference peaks.

$$
\begin{array}{ll}
\text { FWHM }=0.2362^{\circ} & \beta=0.0041 \\
2 \theta=26^{\circ} \quad \theta=13^{\circ} & \cos \theta=0.97 \\
D=0.9 \times 0.154 / 0.0041 \times 0.97 & \\
\text { D }=34.85 \mathrm{~nm} &
\end{array}
$$

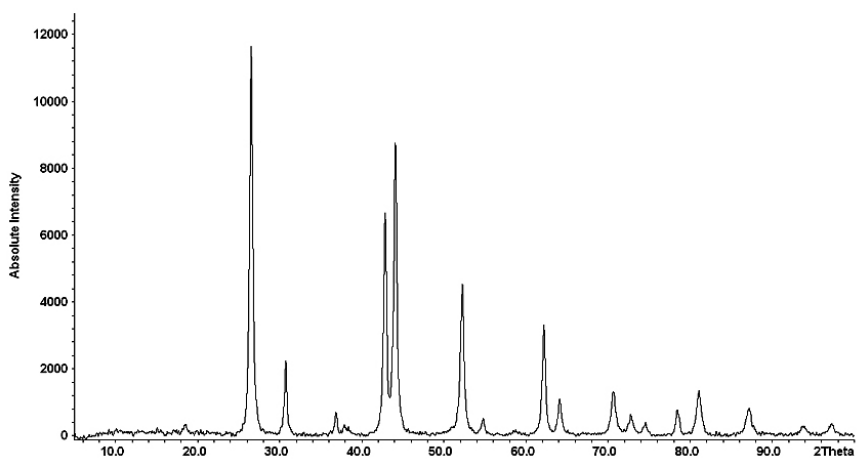

Fig. 8. PXRD pattern of $\mathrm{SrF}_{2}-\mathrm{MgO}$.

\subsection{SEM morphology of the synthesized NPS}

3.4.1. $\mathrm{MgF}_{2} \mathrm{NPS}$

The morphology of synthesized $\mathrm{MgF}_{2}$ NPs were examined by SEM (Fig. 9). The mm-sized crystals and colorless piles were transformed into a white powder and examined. The synthesized NPs are spherical and less than $24 \mathrm{~nm}$. Amorphous dense piles were also observed.

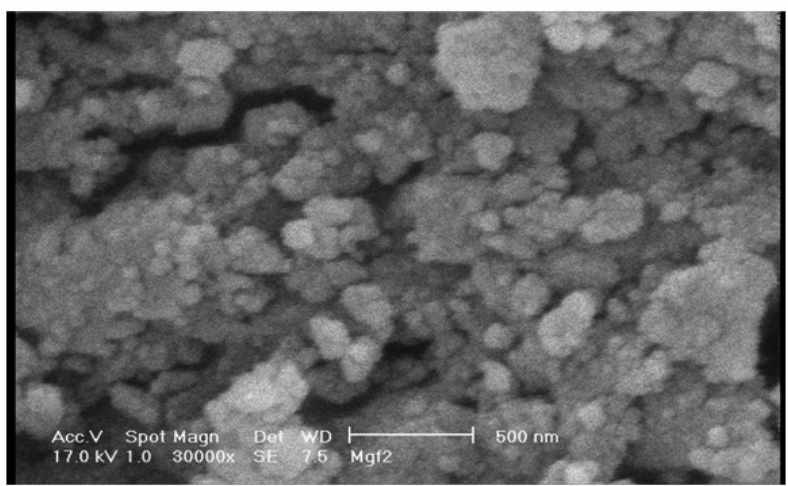

Fig. 9. SEM image of $\mathrm{MgF}_{2} \mathrm{NPs}$.

3.4.2. $\mathrm{SrF}_{2} \mathrm{NPS}$

Compared to its highly crystalline counterpart, the peaks of the $\mathrm{SrF}_{2}$ NPs were much broader, indicating a finer crystal size or a more amorphous structure. SEM analysis (Fig. 10) indicated that the particles ranged from $<$ $50 \mathrm{~nm}$ to about $100 \mathrm{~nm}$ in size. Morphologically, $\mathrm{SrF}_{2} \mathrm{NPs}$ are piled in an amorphous form and aggregated parts can be observed, likely due to the high surface energy of synthesized NPs.

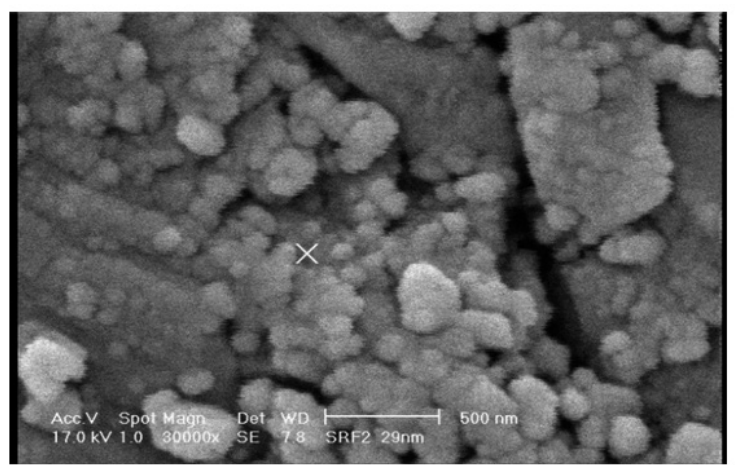

Fig. 10. SEM image of $\mathrm{SrF}_{2} \mathrm{NPs}$. 


\subsection{3. $\mathrm{SrF}-\mathrm{MgO}$ nanocomposite}

In the synthesized $\mathrm{SrF}_{2}-\mathrm{MgO}$ nanocomposite sample (Fig. 11), the number and size distribution of NPs was not uniform, and aggregates were visible. $\mathrm{MgO}$ NPs were observed as large white aggregates on $\mathrm{SrF}_{2} \mathrm{NPs}$. The $\mathrm{MgO}$ NP aggregates were considerably larger than the conjoined and dense $\mathrm{SrF}_{2} \mathrm{NPs}$, likely due to the higher surface energy of $\mathrm{MgO}$ compared to $\mathrm{SrF}_{2} \mathrm{NPs}$.

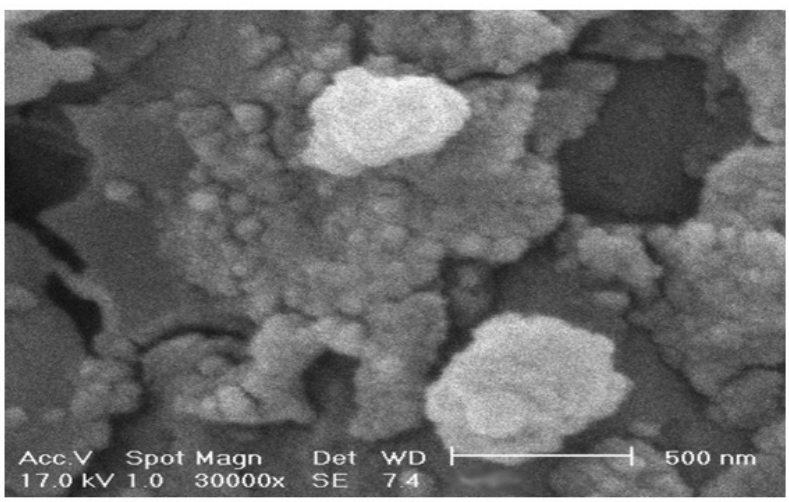

Fig. 11. $\mathrm{SEM}$ image of $\mathrm{SrF}_{2}-\mathrm{MgO}$ nanocomposite.

\subsection{Antibacterial properties}

Since fluoride compounds have antibacterial properties, the effect of the NPs on S. aureus, B. subtilis and E. Aklay bacterial growth was studied. The zone of growth inhibition around each disc was measured and the average results are reported in Table $1 . \mathrm{MgF}_{2}$ and the $\mathrm{SrF}_{2}-\mathrm{MgO}$ nanocomposite inhibited bacterial growth more than $\mathrm{SrF}_{2}^{2}$.

Table 1. The zone of growth inhibition around each bacteria of the synthesized NPs.

\begin{tabular}{|c|c|c|c|}
\hline $\mathbf{N P s}$ & S. aureus & E. Aklay & B. subtilis \\
\hline $\mathrm{SrF}_{2}$ & $2 \mathrm{~mm}$ & - & $2 \mathrm{~mm}$ \\
\hline $\mathbf{M g F}_{2}$ & $4 \mathrm{~mm}$ & $3 \mathrm{~mm}$ & $3 \mathrm{~mm}$ \\
\hline $\mathrm{SrF}_{2}-\mathbf{M g O}$ & $1-2 \mathrm{~mm}$ & $4 \mathrm{~mm}$ & $5 \mathrm{~mm}$ \\
\hline
\end{tabular}

4.

\section{CONCLUSIONS}

NPs were prepared through precipitation and sedimentation. One of the most important benefits of this method is that it can be implemented using standard equipment. Another major advantage is the extremely simple setup. In addition, $\mathrm{SrF}_{2}-\mathrm{MgO}$ nanocomposites were synthesized by ultrasonic waves, the proper method to produce mineral powder nanocomposites. FT-IR absorption was measured to determine the purity of the synthesized powders. For the NPs showed strong absorption peaks due to greater surface to volume ratio, leading to the formation of pores on the surface and inside of dense NPs. The PXRD analysis characterized the crystal structure and average particle size of the NPs which is less than $50 \mathrm{~nm}$. So, SEM images of the NPs approved the nanosized shape and morphology of them. Considering the strength and stability at very high temperatures and the antibacterial properties, $\mathrm{SrF}_{2}-\mathrm{MgO}$ is a valuable composite that can be used in different applications such as dental and material instruments.

\section{ACKNOWLEDGEMENTS}

We appreciatively acknowledge the financial provision from the Research Council of Imam Khomeini International University. DGM (Daniel GlossmanMitnik) is a researcher of CONACYT and CIMAV and acknowledges partial support from both institutions. Acknowledge the financial support of research Office and Faculty of Science UCSC.

\section{REFERENCES}

1. Ghamami, S.; Kazemzade Anari, S.; Bakhshi, M.; Lashgari, A.; SalgadoMorán, G.; Glossman-Mitnik, D., Preparation and Characterization of Cerium (III) Doped Captopril Nanoparticles and Study of their Photoluminescence Properties, Open Chemistry. 14 (1), 60-64, (2016)
2. Lashgari, A.; Ghamami, S.; Bahrami, Z.; Shomossi, F.; Salgado-Morán, G.; Glossman-Mitnik, D.; Morphological Investigation and Fractal Properties of Realgar Nanoparticles, Journal of Nanomaterials, 130698, (2015)

3. Murray, C.B.; Kagan, C..; Bawendi, M.G., Synthesis and Characterization of Monodisperse Nanocrystals and Close-Packed Nanocrystal Assemblies, Annu. Rev. Mater. Sci., 30, 545-610, (2000)

4. Mazzola, L., Commercializing Nanotechnology, Nat. Biotechnol., 21, 1137-1143, (2003)

5. Paull, R.; Wolfe, J.; Heber, P.T.; Sinkula, M., Investing in Nanotechnology, Nat. Biotechnol., 21, 1144-1147, (2003)

6. Lashgari, A.; Ghammamy, S.; Gerli, L.; Salgado Morán, G., Synthesis and Study on Optical Reflection and Photoluminescent Properties of $\mathrm{SiO}_{2} / \mathrm{AgO}$ Nanocomposite., Advances in Environmental Biology, 8(21), 339-345, (2014)

7. Rahmani, A.; Ghammamy, S..; Lashgari, A.; Salgado-Moran, G. Synthesis, Characterization and Properties of New Nano Halo Aluminates, Advances in Environmental Biology, 8(11), 725-729, (2014)

8. Zambaux, M.; Bonneaux, F.; Gref, R.; Maincent, P.; Dellacherie, E.; Alonso, M.; Labrude, P.; Vigneron, C.J., Influence of Experimental Parameters on the Characteristics of Poly(lactic acid) Prepared by a Double Emulsion Method, Journal of Controlled Release. 50, 31-40, (1998)

9. Burda, C.; Che, X.B.; Narayanan, R.; El-Sayed, M.A., Chemistry and Properties of Nanocrystals of Different Shapes, Chem. Rev., 105, 1025$1102,(2005)$

10. Cushing, B.L.; Kolesnichenko, V.L.; O’Connor, C.J., Recent Advances in the Liquid-Phase Synthesis of Inorganic Nanoparticles, Chem. Rev., 104, 3893-3946, (2004)

11. Sun, C.Q., Size Dependence of Nanostructures: Impact of Bond Order Deficiency, Progress in Solid State Chemistry, 35, 1-159, (2007)

12. Alivisatos, A.P., Semiconductor Clusters, Nanocrystals and Quantum Dots, Science, 271, 933-937, (1996)

13. Hu, J.; Odom, T.W.; Lieber, C.M., Chemistry and Physics in One Dimension: Synthesis and Properties of Nanowires and Nanotubes, Acc. Chem. Res., 32, 435-445, (1999)

14. Brus, L.E.; Trautman, J.K., Nanocrystals and Nano-Optics, Philos. Trans. Soc. London Ser. A-Math Phys. Eng. Sci., 353, 313-321, (1995)

15. Heath, J.R., Nanoscale Materials., Acc. Chem. Res., 32, 388, (1999)

16. Marzban, S.; Khorrami, S.A., pH and Properties of Synthesized Barium Hexa-Ferrite by Co-precipitation Method., Int. J. Bio-Inorg. Hybd. Nanomat., 2(4), 491-494, (2013)

17. Afsari, A.; Ranaei, M.A., Equal Channel Angular Pressing to Produce Ultrafine Pure Copper with Excellent Electrical and Mechanical Properties., Int. J. Nanosci. Nanotechnol., 10(4), 215-222, (2014)

18. Ghasemi, A.; Davarpanah, A.M.; Ghadiri, M., Structure and Magnetic Properties of Oxide Nanoparticles of Fe-Co-Ni Synthesized by CoPrecipitation Method., Int. J. Nanosci. Nanotechnol., 8(4), 207-214, (2012)

19. Khayat Sarkar, Z.; Khayat Sarkar, F., Selective Removal of Lead (II) Ion from Wastewater Using Superparamagnetic Monodispersed Iron Oxide $\left(\mathrm{Fe}_{3} \mathrm{O}_{4}\right)$ Nanoparticles as an Effective Adsorbent., Int. J. Nanosci. Nanotechnol., 9(2), 109-114, (2013)

20. Ghobadi, E.; Hemmati, M.; Khanbabaei, G.; Shojaei, M.; Asghari, M., Effect of Nanozeolite 13X on Thermal and Mechanical Properties of Polyurethane Nanocomposite Thin fFilms., Int. J. Nano Dimens., 6(2), 177-181, (2015)

21. Pourasghar, A.; Kamarian, S., Mechanical Material Characterization of an Embedded Carbon Nanotube in Polymer Matrix by Employing an Equivalent Fiber., Int. J. Nano Dimens., 6(2), 167-175, (2015)

22. Sergey I. Pokutnyi, Petr P. Gorbyk, New superatom in alkali-metal atoms, J Nanostruct Chem, 2015, 5 (1), 35-38

23. Jafari, V.; Allahverdi, A., Synthesis and Characterization of Colloidal Nanosilica via an Ultrasound Assisted Route Based on Alkali Leaching of Silica Fume., Int. J. Nanosci. Nanotechnol., 10(3), 145-152, (2014)

24. J. Jasmine Ketzial, A. Samson Nesaraj, Chemical Precipitation of $\mathrm{BaCeO}_{3}-\mathrm{CeO}_{2}$ Based Nano-ceramic Composite Oxide Materials and Their Physical Characterization, Int. J. Nanosci. Nanotechnol., 6(3), 79190, (2010)

25. Pourahmad, A.; Sohrabnezhad, Sh.; Sadeghi, B., Removal of Heavy Metals from Aqueous Solution by Mordenite Nanocrystals, Int. J. Nanosci. Nanotechnol., 6(1), 31-41, (2010)

26. Radhika, D.; Nesaraj, A.S., Chemical Precipitation and Characterization 
of Multicomponent Perovskite Oxide Nanoparticles - Possible Cathode Materials for Low Temperature Solid Oxide Fuel Cell, Int. J. Nano Dimens., 5(1), 1-10, (2014)

27. Saberi, A.; Negahdari, Z.; Bouazza, S.; Willert-Porada, M., synthesis and Characterization of Crystalline Nanosized $\mathrm{MgF}_{2}$ Powder via Microemulsion Route, J. Fluorine Chem, 131, 1353-1355, (2010)

28. Haber, J.; Wojciechowska, M., Surface structure and catalytic properties of the $\mathrm{MoO}_{3}-\mathrm{MgF}_{2}$ system, J. Catal., 110(1), 23-36, (1988)

29. Hunt, G.R.; Perry, C.H., Ferguson, J., Surface Structure and Catalytic Properties of the $\mathrm{MoO}_{3}-\mathrm{MgF}_{2}$ Systems, Phys. Rev., 134, A688-A691, (1964)

30. Nakamoto. K., Infrared and Raman Spectra of Inorganic and Coordination Compounds, in Handbook of Vibrational Spectroscopy, John Wiley \& Sons, 2006.

31. Zhou, L.; Chen, D.; Luo, W.; Wang, Y.; Yu, Y.; Liu, F., Transparent Glass Ceramic Containing $\mathrm{Er}^{3+}: \mathrm{CaF}_{2}$ Nano-Crystals Prepared by Sol-Gel Method, Mater. Lett., 61, 3988-3990, (2007)

32. Huang, X.H.; Chen, Z.H., A Study of Nanocrystalline $\mathrm{NiFe}_{2} \mathrm{O}_{4}$ in a Silica Matrix, Mater. Res. Bull., 40, 105-113, (2005)
33. Lu, L.; Zhu, Y.; Li, F.; Wu, Z.; Chan, K.Y.; Lu, X., Carbon Titania Mesoporous Composite Whisker as Stable Supercapacitor Electrode Materials, J. Mater Chem, 20, 7646-7651, (2010)

34. Kumar, G.A.; Chen, C.W.; Ballato, J.; Riman, R.E., Optical Characterization of Infrared Emitting Rare-Earth-Doped Fluoride Nanocrystals and their Transparent Nanocomposites, Chem. Mater., 19, 1523-1528, (2007)

35. Shekhar Agnihotri, Soumyo Mukherji and Suparna Mukherji, Sizecontrolled silver nanoparticles synthesized over the range 5-100 nm using the same protocol and their antibacterial efficacy, RSC Adv., 2014, 4, 3974-3983].

36. Pandurangappa, C.; Lakshminarasappa, B.N.; Nagabhushana, J., Synthesis and Characterization of $\mathrm{CaF}_{2}$ Nanocrystals, J. Alloys and Compd., 489, 592-595, (2010)

37. Chow, L.C.; Sun, L.; Hockey, B., Properties of Nanostructured Hydroxyapatite Prepared by a Spray Drying Technique, J. Res. Natl. Inst. Stand. Technol., 109, 543-551,(2004) 